\title{
Influence on Immunoreactive Folate-binding Proteins of Extracellular Folate Concentration in Cultured Human Cells
}

\author{
Madeleine A. Kane, "* Patrick C. Elwood,' R. M. Portillo,' Asok C. Antony," Vesna Najfeld,' Andrew Finley," \\ Samuel Waxman, "' and J. Fred Kolhouse" \\ *Cancer Chemotherapy Foundation Laboratory, and Departments of ${ }^{\ddagger}$ Neoplastic Diseases and 'Medicine, Mt. Sinai Medical Center, \\ New York 10029; "Divisions of Hematology and Oncology, Indiana University School of Medicine, Indianapolis, Indiana 46223; \\ ${ }^{\S}$ Divisions of Hematology and Medical Oncology, University of Colorado Health Sciences Center, Denver, Colorado 80262
}

\begin{abstract}
The influence of extracellular folate concentration on cellular levels of the folate transport protein and its soluble product was studied directly in cultured human nasopharyngeal carcinoma (KB) cells. As determined by radioimmunoassay, levels of the folate transport protein and the soluble folate-binding protein were $58 \pm 17$ (mean \pm SD) and $5 \pm 2 \mathrm{pmol} / \mathrm{mg}$ cell protein, respectively, in $\mathrm{KB}$ cells maintained in standard medium (containing 2,300 $\mathrm{nM}$ folic acid). These levels significantly increased to $182 \pm 34$ and $26 \pm 6 \mathrm{pmol} / \mathrm{mg}$ cell protein, respectively, in $\mathrm{KB}$ cells serially passaged in low folate medium (containing 2-10 nM 5-methyltetrahydrofolate). Increases in folate-binding protein levels occurred more rapidly in $\mathrm{KB}$ cells serially passaged in very low folate medium containing $<2 \mathrm{nM}$ folate and were prevented by the addition of $100 \mathrm{nM} 5$-methyltetrahydrofolate or 0.1-1 $\mu$ M 5-formyltetrahydrofolate to this medium. When KB cells which had been passaged in low folate medium were passaged back into either standard medium or low folate medium supplemented with reduced folates, the levels of both folate-binding proteins fell linearly towards the levels in KB cells continuously maintained in standard medium. The folate transport protein was identified in and underwent similar changes in human and mouse mammary tumor cells. These studies indicate that the folate transport system is probably regulated by the extracellular folate concentration through changes in intracellular metabolite levels.
\end{abstract}

\section{Introduction}

High-affinity folate-binding proteins (FBP) ${ }^{1}$ have been identified in and purified from a number of mammalian and human

Portions of this work were presented at the meetings of the American Society of Hematology, Miami, FL, December 1984, and New Orleans, LA, December 1985.

Address reprint requests to Dr. Kane at her present address: Research Service (151), Denver VA Medical Center, 1055 Clermont Street, Denver, CO 80220.

Received for publication 1 May 1987 and in revised form 3 October 1987.

1. Abbreviations used in this paper: FBP, folate-binding protein; KB, human epidermoid carcinoma (cells); LMEM, folic acid-free MEM supplemented with $10 \%$ (vol/vol) FBS; LMEM-D, folic acid-free MEM supplemented with $10 \%$ (vol/vol) dialyzed FBS; SMEM, standard MEM supplemented with $10 \%$ (vol/vol) FBS; SMEM-D, standard MEM supplemented with $10 \%$ (vol/vol) dialyzed FBS.

J. Clin. Invest.

(c) The American Society for Clinical Investigation, Inc.

0021-9738/88/05/1398/09 \$2.00

Volume 81, May 1988, 1398-1406 sources (1-25). Recently the membrane-associated FBP of cultured human epidermoid carcinoma (KB) cells was shown to be involved in 5-methyltetrahydrofolate $\left(5-\mathrm{CH}_{3} \mathrm{H}_{4} \mathrm{PteGlu}\right)$ and folic acid (PteGlu) transport in intact cells (20). This membrane-associated FBP also bound large quantities of the chemotherapeutically active folate analogue, methotrexate, in $\mathrm{KB}$ cells grown in a physiologic concentration and form of folate (26), suggesting a role for this folate transport protein in methotrexate transport and/or storage.

Soluble FBPs have been found in serum $(2,17)$, milk $(1,2$, $8,13,16)$, specific granules of leukocytes $(3,4,10,17)$, and human spleen (25). Human lymphocytes in culture (18) and KB cells (22-24) released soluble FBP into their growth medium. The KB cell soluble FBP was immunologically crossreactive with $\mathrm{KB}$ cell folate transport protein (22-24), as well as human placental folate receptor and human milk folate binding proteins $(22,23)$. Several functions have been suggested for soluble FBP, but none has been proven $(3,6,9,13$, 20, 27-34).

A precursor-product relationship between the cell-associated folate transport protein and the soluble FBP released by human KB cells has recently been demonstrated by pulsechase studies (22). Both proteins were purified to homogeneity and have been more thoroughly biochemically characterized as glycoproteins, with the folate transport protein exhibiting considerable hydrophobicity (23), consistent with its membrane location and transport function.

Levels of membrane-associated receptors and transport proteins may be upregulated or downregulated depending upon the availability of their effector molecules $(35,36)$. Thus, the levels of the folate transport protein and its soluble product could be affected by the availability of the effector molecules (folates) to the cell. The effects of extracellular folate concentration and cellular folate content on levels of folate transport protein and soluble FBP have not been studied directly. However, in $\mathrm{KB}$ cells cultured in growth medium containing a low folate concentration (3-10 $\mathrm{nM}$ ): (a) the amount of $\left[{ }^{3} \mathrm{H}\right] \mathrm{PteGlu}$ which bound to acid-washed particulate membrane preparations was increased (30); (b) the amount of folate specifically accumulated by intact KB cells was increased 10-40-fold (19, 20); (c) the amount of methotrexate specifically accumulated increased fivefold (26); and $(d)$ the amounts of cell-associated folate transport protein and its product increased as measured by $\left[{ }^{3} \mathrm{H}\right]$ PteGlu binding (24) compared with $\mathrm{KB}$ cells cultured in standard medium (2,300 $\mathrm{nM}$ folic acid). Increased specific binding and uptake of $5-\mathrm{CH}_{3} \mathrm{H}_{4}$ PteGlu by folate-deficient cultured monkey kidney MA 104 cells was also recently reported (21). The amount of radioactive PteGlu taken up by the livers of folated-deprived rats was also increased (37). Conversely, the lack of folate binding in Lactobacillus casei cultured in medium containing $10 \mu \mathrm{M}$ PteGlu was interpreted as 
repression of the FBP by the presence of high folate levels (38). Although these studies suggested changes in the levels of FBPs, the results could not distinguish between changes in the number of available binding sites and changes in actual amounts of FBP since quantitation relied on ligand binding or uptake. Thus, these results could suggest upregulation of the FBPs when the true quantity of FBPs was unchanged. Furthermore, downregulation in high folate medium could appear to occur but merely be the result of incomplete removal of endogenous ligand.

Using a radioimmunoassay (RIA), daCosta and co-workers found that compared to sera of healthy humans, the level of soluble FBP was increased in sera of individuals with a variety of conditions including folate deficiency $(12,39)$. However, the cellular folate transport protein was not measured in these studies, and it was unknown whether the increased level of soluble FBP in the sera of these subjects was a reflection of increased synthesis of soluble FBP, altered clearance of soluble FBP, or both.

Since standard commercially available tissue culture media contain supraphysiologic levels of folate, we wondered whether FBP levels observed in cells cultured in standard media might be artifactually different from levels in cells cultured in medium containing more physiologic levels of folate. In the present study, the changes in the levels of folate transport protein and soluble FBP in KB cells exposed to standard and specially prepared media containing different extracellular folate concentrations and forms were studied. Initially, folate transport protein and soluble FBP were quantified by $\left[{ }^{3} \mathrm{H}\right]-$ PteGlu binding. However, to eliminate the ambiguity possibly introduced by using radioactive folate binding to quantify FBP levels, an RIA was constructed to measure each FBP directly. Small quantities of folate transport protein and soluble FBP were purified from KB cells and their conditioned medium, respectively, the latter was radiolabeled, and both were utilized as standards in developing the RIAs. This is the first study to directly determine the effect of extracellular folate concentrations on the levels of the immunoreactive folate transport protein and its product, soluble FBP, in a defined system.

\section{Methods}

Materials. Human KB cells (ATCC No. CCL 17), passage No. 363, and human fibroblasts were obtained frozen from the American Type Culture Collection, Rockville, MD. Human T47D mammary tumor cells were obtained from Dr. Kathryn Horwitz, Division of Endocrinology, University of Colorado Health Sciences Center, Denver, CO. Mouse alpha mammary tumor cells were obtained from Dr. Mary Jane Yagi, Department of Neoplastic Diseases, Mt. Sinai Medical Center, New York. Normal human lymphocytes were prepared from the whole blood of a volunteer by Ficoll-Hypaque density gradient centrifugation after erythrocyte removal (18). Eagle's minimum essential medium (MEM) with and without folic acid, fetal bovine serum (FBS), penicillin and streptomycin, trypsin-EDTA, 10X, and chicken control serum were purchased from Gibco, Grand Island, NY.

$\left[3^{\prime}, 5^{\prime}, 7,9-{ }^{3} \mathrm{H}\right] \mathrm{PteGlu}, 5 \mathrm{Ci} / \mathrm{mmol}, \mathrm{Na}^{125} \mathrm{I}, 13-17 \mathrm{mCi} / \mu \mathrm{g} \mathrm{I}$, and Bolton and Hunter reagent, 2,000 Ci/mmol, were obtained from Amersham Corp., Arlington Heights, IL. The purity of the radioactive PteGlu used in these studies was $>99 \%$ by HPLC analysis (20). (D,L)5-methyltetrahydrofolate and (D,L)-5-formyltetrahydrofolate were purchased from Sigma Chemical Co., St. Louis, MO. HPLC analysis revealed a purity of $>90 \%$ and $>99 \%$, respectively. Dextran T70 was from Pharmacia Fine Chemicals, Piscataway, NJ. Neutral Norit Char- coal was obtained from Fisher Scientific, Fair Lawn, NJ. Polyethylene glycol 6000 was obtained from Sigma Chemical Co. All other reagents and chemicals were analytical grade and from either Fisher Scientific, or Sigma Chemical Co.

Propagation of $K B$ cells. $\mathrm{KB}$ cells were propagated as previously described $(20,22-24)$ in four different media: $(a)$ standard MEM supplemented with $10 \%$ (vol/vol) FBS (SMEM); $(b)$ folic-acid-free MEM supplemented with $10 \%$ (vol/vol) FBS (low-folate MEM or LMEM); (c) standard MEM supplemented with $10 \%$ (vol/vol) dialyzed FBS (SMEM-D); and $(d)$ folic-acid-free MEM supplemented with $10 \%$ (vol/vol) dialyzed FBS (LMEM-D). SMEM and SMEM-D contained $2.3 \mu \mathrm{M}$ PteGlu. LMEM contained $\sim 10 \mathrm{nM}$ folate as predominantly 5- $\mathrm{CH}_{3} \mathrm{H}_{4}$ PteGlu from FBS; LMEM-D contained $<2 \mathrm{nM}$ 5- $\mathrm{CH}_{3} \mathrm{H}_{4} \mathrm{PteGlu}$ (24). In some experiments, LMEM-D was supplemented with $100 \mathrm{nM} 5-\mathrm{CH}_{3} \mathrm{H}_{4} \mathrm{PteGlu}$ or $0.1-1 \mu \mathrm{M} 5-\mathrm{CHOH}_{4} \mathrm{PteGlu}$ as indicated.

Before cell harvest, conditioned growth medium was decanted, pooled, and frozen for later purification of the soluble FBP. KB cells were harvested and resuspended in SMEM, LMEM, SMEM-D, or LMEM-D as appropriate. A passage was defined as splitting one flask of near-confluent $\mathrm{KB}$ cells into two flasks of equal volume. Passages were carried out every 48-96 h. Single-cell suspensions were obtained by vigorously pipetting the entire volume of the cell suspension against the wall of the container 10 times. Cells were quantified by counting on a Coulter Counter, model No. 2 F (Coulter Electronics, Inc., Hialeah, FL); values were reproducible and agreed within $10 \%$ with counts obtained manually by hemocytometer or by protein determinations (see below). Cell size was estimated by comparison of size distribution profiles on the $\mathrm{x}-\mathrm{y}$ recorder attached to the Coulter Counter with the size distribution profiles of latex beads of known diameter. Cell viability was $>90 \%$ in all experiments as determined by trypan blue exclusion (40). Growth curves to obtain cell-doubling times were performed by plating cells $\left(1-2 \times 10^{5}\right.$ cells $\left./ \mathrm{ml}\right)$ into $1.6-\mathrm{cm}$ diam wells in tissue culture cluster plates (Costar, Cambridge, MA), and harvesting wells in quadruplicate with trypsin-EDTA for cell counts at different times after plating.

Human fibroblasts, human T47D cells, and mouse alpha mammary tumor cells were cultured and harvested in SMEM as for KB cells unless otherwise indicated.

Gel filtration analysis. Cells were solubilized in Triton X-100 and analyzed by Sephacryl S-200 gel filtration chromatography as previously described $(22,23)$.

Purification of folate transport protein and soluble FBP. KB cell folate transport protein and soluble FBP from KB cell-conditioned medium were purified as previously described $(22,23)$.

Analysis of FBP by $\left[{ }^{3} \mathrm{H}\right]$ PteGlu binding. For analysis of soluble FBP and folate transport protein by $\left[{ }^{3} \mathrm{H}\right] \mathrm{PteGlu}$ binding, samples of conditioned medium and samples of $\mathrm{KB}$ cells were collected at indicated times after plating. Conditioned medium was centrifuged at $30,000 \mathrm{~g}$ to remove cell debris containing folate transport protein (23), and folate transport protein was solubilized from intact cells in potas-

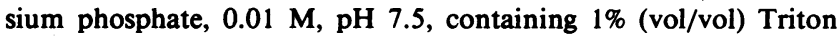
$\mathrm{X}-100$ for $48 \mathrm{~h}$ at $4^{\circ} \mathrm{C}$ as previously described (20). Samples were then dialyzed against $100 \mathrm{vol}$ of acetic acid, $0.2 \mathrm{M}, \mathrm{pH} 2.7$, for at least $48 \mathrm{~h}$ at $4^{\circ} \mathrm{C}$ with buffer changes twice daily to remove endogenous folate, and then dialyzed against 100 vol of potassium phosphate, $0.01 \mathrm{M}, \mathrm{pH}$ 7.5 , containing $\mathrm{NaCl}, 0.15 \mathrm{M}$ (buffered saline), for $24 \mathrm{~h}$ with two buffer changes to raise the sample $\mathrm{pH}$ for the binding assay (22). Triton $\mathrm{X}-100,1 \%$ (vol/vol) was added to the dialysis buffer of the folate transport protein samples. Aliquots of purified folate transport protein and soluble FBP were analyzed to determine the number of moles present, assuming a binding stoichiometry of one molecule of FBP to one molecule of PteGlu (23). A final assay volume of $1 \mathrm{ml}$ contained $1 \%$ (vol/vol) Triton X-100, an aliquot of sample to be assayed, $20 \mu \mathrm{l}$ of $500 \mathrm{nM}\left[{ }^{3} \mathrm{H}\right] \mathrm{PteGlu}(\sim 22,000 \mathrm{cpm}$; added last to give a final concentration of $10 \mathrm{nM}$ ) and buffered saline $(13,14,19,20,22-24)$. After samples were incubated at $37^{\circ} \mathrm{C}$ for $30 \mathrm{~min}$, they were cooled to $4^{\circ} \mathrm{C}$. To adsorb unbound $\left[{ }^{3} \mathrm{H}\right] \mathrm{PteGlu}$, dextran-coated charcoal $(41), 1 \mathrm{ml}$, 
was added at $4^{\circ} \mathrm{C}$, vortexed twice, and incubated at $4^{\circ} \mathrm{C}$ for $10 \mathrm{~min}$ The charcoal was pelleted by centrifugation at $4,000 \mathrm{~g}$ for $10 \mathrm{~min}$, and an aliquot of supernatant was counted by liquid scintillation. Blank supernatants (no FBP sample) contained $3-3.5 \%$ of the added $\left[{ }^{3} \mathrm{H}\right]$ PteGlu and were subtracted from values obtained from FBP samples. Sample amounts were adjusted so that between $10 \%$ and $35 \%$ of the net counts per minute added remained in the supernatant after charcoal treatment. More than $75 \%$ of the total $\left[{ }^{3} \mathrm{H}\right] \mathrm{PteGlu}$ radioactivity could be retained in the supernatant by increasing the amount of FBP added. At least two different volumes of sample were analyzed together so that assay linearity could be ensured.

Iodination of the soluble FBP. The purified soluble FBP was iodinated by the chloramine-T method (42) at $22^{\circ} \mathrm{C}$ as follows. A sample containing $10 \mu \mathrm{g}$ of purified soluble FBP in $1 \mathrm{ml} 0.1 \mathrm{M}$ potassium phosphate, $\mathrm{pH}$ 7.5, was incubated with $10 \mu \mathrm{M}$ cold PteGlu to saturate folate-binding sites. $\mathrm{Na}^{125} \mathrm{I}, 1 \mathrm{mCi}$ in $2 \mu \mathrm{l}$, was added. Chloramine T, 4 $\mathrm{mg} / \mathrm{ml}$, in the same buffer, $160 \mu \mathrm{l}$, was added and mixed for $15 \mathrm{~s}$. Then $\mathrm{NaHSO}_{3}, 2.4 \mathrm{mg} / \mathrm{ml}$, in the same buffer, $100 \mu \mathrm{l}$, was added immediately and mixed for $15 \mathrm{~s}$, followed immediately by $\mathrm{KI}, 1 \mathrm{M}, 250 \mu \mathrm{l} .4$ $\mathrm{ml}$ of the same buffer, but containing bovine serum albumin (BSA), 20 $\mu \mathrm{g} / \mathrm{ml}$, was next added. The iodinated soluble FBP was isolated at $4^{\circ} \mathrm{C}$ using a Sephacryl S-200 gel filtration column, $2.5 \times 30 \mathrm{~cm}$, preequilibrated, and eluted with buffered saline containing BSA, $10 \mu \mathrm{g} / \mathrm{ml}$. Fractions of $2.6 \mathrm{ml}$ were analyzed for radioactivity directly. An identical column was calibrated with the following standards of known molecular weight: blue dextran $2000\left(M_{\mathrm{r}}=2 \times 10^{6}\right)$, human hemoglobin $\left(M_{\mathrm{r}}=64,000\right)$, soluble FBP $\left(M_{\mathrm{r}}=40,000\right)$, and cytochrome $c\left(M_{\mathrm{r}}\right.$ $=14,500)$. Fractions from the radioactive peak which eluted at $V_{\mathrm{e}} / V_{\mathrm{o}}$ $=1.4-1.8$, (which corresponded to the elution position of $\mathrm{KB}$ cell soluble FBP), were pooled for use in the RIA. A satisfactory preparation of ${ }^{125}$ I-labeled soluble FBP was also obtained using the Bolton and Hunter method of iodination as previously described (43).

Polyacrylamide gel electrophoresis (PAGE) and autoradiography. ${ }^{125}$ I-labeled soluble FBP was analyzed by PAGE in $0.1 \%$ sodium dodecyl sulfate (SDS) on 5-20\% polyacrylamide gradient slab gels and visualized by Coomassie blue staining and autoradiography, respectively $(44,45)$.

Development of the RIA. An RIA utilizing purified placental folate receptor as the standard and the iodinated protein and rabbit antiserum has recently been reported (46). The source of monospecific antibody in this RIA was chicken anti-human placental folate receptor antiserum (14). The amount of antiserum which would precipitate $70 \%$ of $10,000 \mathrm{cpm}$ of ${ }^{125}$ I-labeled soluble FBP was determined. Various amounts of the specific antiserum diluted in chicken control serum to a total volume of $100 \mu \mathrm{l}$ were incubated with the ${ }^{125} \mathrm{I}$-labeled soluble FBP. An additional $100 \mu$ l of chicken control serum, $11.3 \mathrm{nmol}$ nonradioactive PteGlu, $1 \%$ (vol/vol) Triton X-100, $0.05 \mathrm{M} \mathrm{NaCl}, 0.01$ $\mathrm{M}$ potassium phosphate, $\mathrm{pH} 7.5$, and distilled water were added to make a total volume of $700 \mu \mathrm{l}$. The incubation proceeded for $18 \mathrm{~h}$ at $4^{\circ} \mathrm{C}$. An antigen-antibody precipitation curve was constructed for each new batch of ${ }^{125} \mathrm{I}$-labeled soluble FBP. Duplicate samples containing only control serum were the controls. After incubation as above, the antigen-antibody complexes were precipitated by the addition, with mixing, of $300 \mu \mathrm{l}$ of polyethylene glycol $6000,30 \%$ (wt/vol), in $0.05 \mathrm{M}$ potassium phosphate, $\mathrm{pH} 7.5$, containing $0.75 \mathrm{M} \mathrm{NaCl}$, at $4^{\circ} \mathrm{C}$ for 10 min as previously described (13), followed by centrifugation in a Microfuge B (Beckman Instruments, Inc., Fullerton, CA) at $12,000 \mathrm{~g}$ for 2 min at $22^{\circ} \mathrm{C}$. The supernatant was aspirated and the pellets counted directly as described below. Dissolution of pellets in $1 \mathrm{ml}$ of distilled water resulted in counts similar to those obtained with the solid pellets.

Standard curves were constructed using each of the purified folate binding proteins. Dilutions of the purified proteins were shaken for 18 $h$ at $4^{\circ} \mathrm{C}$ with $50-100 \mu \mathrm{l}$ (depending upon the antigen-antibody precipitation curve) of monospecific antiserum which had been diluted 1:100 in chicken control serum as described above. The ${ }^{125} \mathrm{I}$-labeled soluble FBP was then added to each sample to make a total volume of $700 \mu 1$, and the samples were shaken for an additional $18 \mathrm{~h}$ at $4^{\circ} \mathrm{C}$. The antigen-antibody complexes were precipitated with polyethylene gly- col and the radioactivity determined as described above. A complete standard curve for folate transport protein or soluble FBP was analyzed with each set of cell or conditioned medium samples. For analysis of folate transport protein, cells were harvested without trypsin by the addition of buffered saline containing Triton X-100, 1\% (vol/vol), directly to the monolayer in the flask followed by three cycles of freeze-thawing, or by incubation with $20 \mathrm{mM}$ EDTA in buffered saline for $30 \mathrm{~s}$ at $37^{\circ} \mathrm{C}$ as previously described $(23,24)$. Either method gave identical results. Cells were quantified by protein analysis as described below, or by cell counts. Aliquots of solubilized cells containing folate transport protein were analyzed as for the FBP standards, and the amount of folate transport protein present determined from the standard curve. Conditioned medium was analyzed as for soluble FBP standards after centrifugation at $30,000 \mathrm{~g}$ for $30 \mathrm{~min}$ at $4^{\circ} \mathrm{C}$ to remove particulate cell debris containing folate transport protein $(22,23)$. Aliquots of samples of conditioned growth medium were diluted with unexposed SMEM to a total volume of $400 \mu \mathrm{l}$ of growth medium in each sample. Unexposed (fresh) SMEM, $400 \mu l$, was also added to each standard and control.

Folate assays. Total folate was assayed in $\mathrm{KB}$ cells and growth medium using a competitive radioligand binding assay with $\left[{ }^{3} \mathrm{H}\right]-$ PteGlu, PteGlu standards, and $\beta$-lactoglobulin as the FBP $(41,47)$.

Protein determinations. Sample protein levels were determined by the method of Lowry et al. (48) which was modified for samples containing Triton X-100 (49). BSA served as the standard.

Determination of radioactivity in samples. Samples containing ${ }^{125} \mathrm{I}$ were counted directly in a Searle Analytic Gamma Counter, model 1185. Samples containing ${ }^{3} \mathrm{H}$ were counted by liquid scintillation in a Beckman Instruments, Inc. LS 250. The total volume of aqueous sample was adjusted to $1 \mathrm{ml}$ with distilled $\mathrm{H}_{2} \mathrm{O}$, and $10 \mathrm{ml}$ ScintiVerse I (Fisher Scientific) were added. The counting efficiency for ${ }^{3} \mathrm{H}$ was $40 \%$.

Statistics. Student's $t$ test was used to analyze differences in folate transport protein and soluble FBP levels in KB cells cultured in different extracellular folate concentrations (50).

Cytogenetics. Karyotypes of KB cells maintained for 18 passes in LMEM or 19 passes in SMEM were performed by previously published methods $(51,52)$.

\section{Results}

Properties of intact $K B$ cells grown in different extracellular folate concentrations. KB cells were readily maintained in LMEM for more than 40 passages $(10 \mathrm{mo})$ as observed by others (30). The growth rate of KB cells cultured in LMEM slowed after five to six serial passes (doubling time $35 \mathrm{~h}$ ), and apparent average cell size increased from $14.7 \mu \mathrm{m}$ as for $\mathrm{KB}$ cells maintained in SMEM to $18 \mu \mathrm{m}$ in diameter. However, after 12-15 passes in LMEM, the growth rate and size became indistinguishable from that of KB cells cultured in SMEM (doubling time $24 \mathrm{~h}$ ). The karyotypes of KB cells maintained in LMEM or SMEM for 18 or 19 passes were indistinguishable, with no double minute chromosomes or homogeneous staining regions identified. KB cells cultured in SMEM-D exhibited a doubling time of $36 \mathrm{~h}$, indicating that dialyzable factors in FBS other than the folate were necessary to maintain the usual growth rate. The doubling time of KB cells propagated in LMEM-D increased to $48 \mathrm{~h}$ after five to six passages in this medium, but after 10-15 passages, these KB cells again "adapted" to growth in low folate medium with a decrease in their doubling time to $36 \mathrm{~h}$. When $\mathrm{KB}$ cells, serially passed five to six times in LMEM-D, were passed into LMEM-D supplemented with either $100 \mathrm{nM} 5-\mathrm{CH}_{3} \mathrm{H}_{4}$ PteGlu or $1 \mu \mathrm{M}$ 5$\mathrm{CHOH}_{4} \mathrm{PteGlu}$, growth rates returned to those of $\mathrm{KB}$ cells maintained in SMEM-D within $24 \mathrm{~h}$. 
The folate content of KB cells maintained in SMEM was 50-60 pmol $/ 10^{6}$ cells. The folate content of $\mathrm{KB}$ cells maintained in LMEM fell rapidly over five passes to $\sim 1 \mathrm{pmol} / 10^{6}$ cells, similar to previously reported results (26), but the folate content in KB cells after more than 20 passes in LMEM remained at $\sim 1 \mathrm{pmol} / 10^{6}$ cells. The folate content of $\mathrm{KB}$ cells cultured in SMEM-D was $20-25 \mathrm{pmol} / 10^{6}$ cells, as previously reported (26). For cells in LMEM-D, the folate content fell to a low of $0.3 \mathrm{pmol} / 10^{6}$ cells after the fourth serial passage and subsequently increased slightly to $0.6-0.8 \mathrm{pmol} / 10^{6}$ cells in passages 5-8 despite continued doubling in LMEM-D. The doubling time of KB cells grown in LMEM-D for 5-10 passages "normalized" after three passages back into SMEM-D, which was when their cellular folate content exceeded 1 pmol $/ 10^{6}$ cells.

Effect of extracellular folate concentration on folate transport protein and soluble FBP measured by $\left[{ }^{3} \mathrm{H}\right]$ PteGlu specific binding. As previously reported $(22,23), \mathrm{KB}$ cells contained no soluble FBP, and $>90 \%$ of the membrane-associated debris in the conditioned medium was removed by centrifugation at $30,000 \mathrm{~g}$ for $30 \mathrm{~min}$ at $4^{\circ} \mathrm{C}$ or by passage through a $0.22-\mu \mathrm{m}$ filter. Thus, this compartmentation simplified analysis of the levels of cell-associated folate transport protein in the KB cells and soluble FBP in their conditioned medium since the two proteins did not need not to be separated from each other prior to assay, except as described above (22).

As shown in Fig. $1 \mathrm{~A}$, the levels of folate transport protein measured by $\left[{ }^{3} \mathrm{H}\right] \mathrm{PteGlu}$ binding to acid-dialyzed Triton $\mathrm{X}-100$ extracts of $\mathrm{KB}$ cells grown in LMEM for 12-13 passes were elevated approximately threefold over levels in KB cells grown in SMEM. The amount of folate transport protein per $\mathrm{mg}$ cell protein did not change with time for at least $48 \mathrm{~h}$ after plating of cells. Levels of soluble FBP measured by $\left[{ }^{3} \mathrm{H}\right]$ PteGlu binding were also elevated in the conditioned medium of $\mathrm{KB}$ cells grown in LMEM compared with those grown in SMEM as shown in Fig. $1 B$. Levels of soluble FBP per milligram cell protein in the conditioned medium increased with time after plating as shown.

Since KB cells contain $\sim 0.3 \mathrm{mg}$ protein $/ 10^{6}$ cells as de-

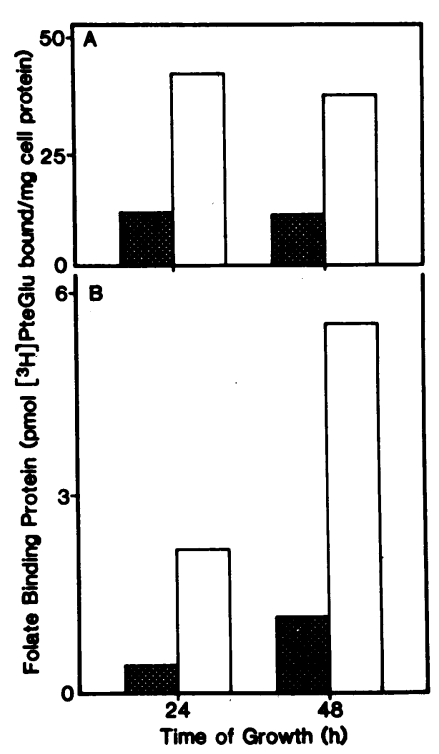

Figure 1. FBPs measured by $\left[{ }^{3} \mathrm{H}\right]$ PteGlu binding in aciddialyzed samples from $\mathrm{KB}$ cells maintained in SMEM (13 passes, darkened bars) or LMEM (12 passes, white bars). Folate binding was determined using $\left[{ }^{3} \mathrm{H}\right] \mathrm{PteGlu}, 10 \mathrm{nM}$, in Triton X-100 solubilized KB cell extracts (folate transport protein) and their centrifuged conditioned media (soluble FBP) obtained 24 and $48 \mathrm{~h}$ after plating and prepared as described in Methods. Values shown are means of duplicate samples assayed in quadruplicate, and standard deviations were $<10 \%$ of the means. $(A)$ Folate transport protein. $(B)$ Soluble FBP. termined by modified Lowry analysis, the cellular folate levels were $\sim 160 \mathrm{pmol} / \mathrm{mg}$ cell protein in cells maintained in SMEM, markedly in excess of the folate transport protein levels of $10 \mathrm{pmol} / \mathrm{mg}$ cell protein as measured by $\left[{ }^{3} \mathrm{H}\right] \mathrm{PteGlu}$ binding. However, in KB cells maintained for twelve passes in LMEM, the folate transport protein levels of $35-40 \mathrm{pmol} / \mathrm{mg}$ cell protein exceeded the cellular folate content of 3-5 pmol/ $\mathrm{mg}$ cell protein by 7-13-fold.

Construction of the RIAs for folate transport protein and soluble FBP. Folate transport protein was purified to apparent homogeneity from $10^{8}$ intact $\mathrm{KB}$ cells as previously described $(22,23)$ with an overall recovery of $67 \%$. Soluble FBP was purified from 3 liters of centrifuged conditioned growth medium as previously described $(22,23)$ with an overall recovery of $36 \%$. Assuming a $1: 1$ stoichiometry of $\left[{ }^{3} \mathrm{H}\right]$ folic acid binding to each FBP, the molecular weights calculated using binding data and Lowry protein analysis were 29,000 for the soluble FBP and 45,000 for the folate transport protein, which agree reasonably well with our $M_{\mathrm{r}}$ estimate from SDS-PAGE for soluble FBP as shown below and with reported results (23).

The apparent homogeneity of the soluble FBP was maintained after iodination as shown in Fig. 2. SDS-PAGE analysis of the ${ }^{125}$ I-labeled soluble FBP revealed a single Coomassie blue-staining band which coincided with a single band on the autoradiogram of the same gel. This band had an estimated $M_{\mathrm{r}}$ of 31,000 compared with standards of known $M_{\mathrm{r}}$ analyzed on the same gel, and this value compared well with the calculated $M_{\mathrm{r}}$ of purified soluble FBP previously reported (23). In addition, as shown in Fig. 3, >95\% of the ${ }^{125}$ I-labeled soluble FBP was precipitable with increasing amounts of the monospecific antiserum to the purified placental folate receptor (14) while $<5 \%$ was precipitable with control serum.

Standard curves using the purified KB cell folate transport protein or soluble FBP were linear over a 10 -fold range (0.5-5 pmol) as shown in Fig. 4. Close structural relationship between the cell-associated folate transport protein and soluble FBP is illustrated by their virtually identical immunologic cross-reactivity with the human placental folate receptor antiserum (14) in the standard curve for the RIA. Results were $<5 \%$ different

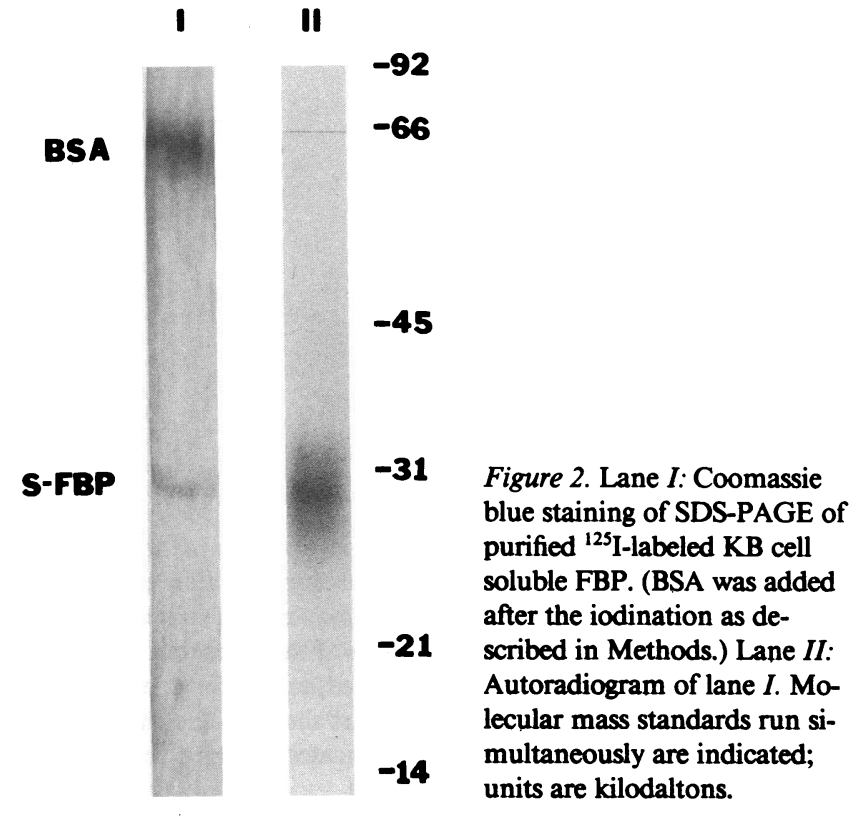




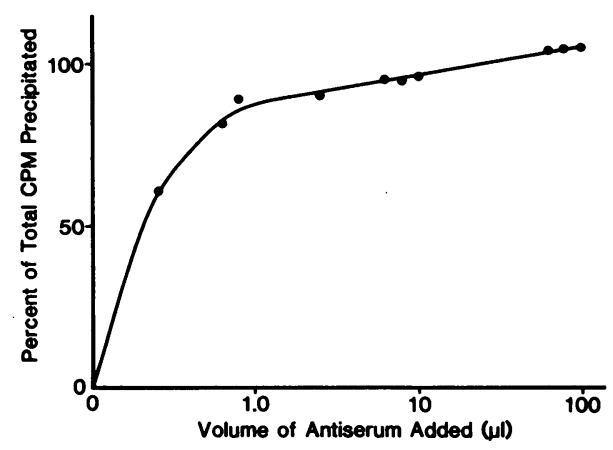

Figure 3. Precipitation of ${ }^{125} \mathrm{I}$-labeled soluble FBP by monospecific chicken anti-human placental folate receptor antiserum. The total incubation volume was $700 \mu l$ as described in Methods.

in the presence of added saturating amounts of folic acid, indicating that both apo and holo forms of the cell-associated folate transport protein and soluble FBP had very similar immunoreactivity. The standard curve does not quite pass through $100 \%$ because the ${ }^{125}$ I-labeled soluble FBP is probably slightly less immunoreactive than the native purified proteins.

Effect of folate concentration in the growth medium on the levels of immunoreactive folate transport protein and soluble $F B P$. The folate transport protein level in $\mathrm{KB}$ cells serially passaged more than 20 times in LMEM was $182 \pm 34$ (mean $\pm \mathrm{SD}, n=19) \mathrm{pmol} / \mathrm{mg}$ cell protein compared with $58 \pm 17 \mathrm{pmol} / \mathrm{mg}$ cell protein $(n=12)$ for KB cells maintained in SMEM for a similar number of passages $(P<0.001)$. The soluble FBP levels were $26 \pm 6 \mathrm{pmol} / \mathrm{mg}$ cell protein $(n=8)$ and $5 \pm 2 \mathrm{pmol} / \mathrm{mg}$ cell protein $(n=3)$ for conditioned media of KB cells cultured more than 20 passes in LMEM or SMEM, respectively $(P<0.001)$. As shown in Fig. $5 A$, folate transport protein progressively increased as $\mathrm{KB}$ cells were serially passed through LMEM until a plateau was reached after almost 30 passes. A similar increase in soluble FBP was also observed. The amount of folate transport protein per $\mathrm{mg}$ cell protein measured by RIA remained constant for $96 \mathrm{~h}$ after KB cells were plated into either LMEM or SMEM. Soluble FBP levels per milligram cell protein measured by RIA increased with time after plating. Therefore, the soluble FBP data in Fig. 5

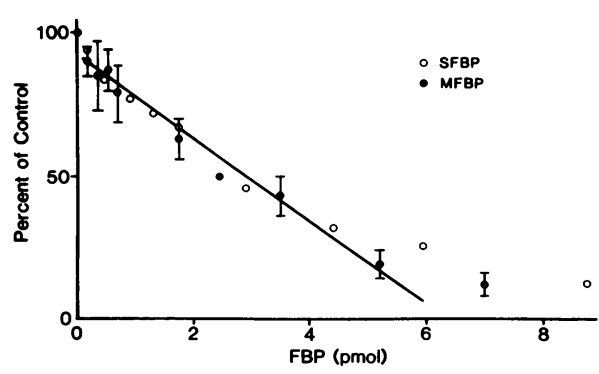

Figure 4. Standard curves for folate transport protein (๑) and soluble FBP (0) in the radioimmunoassay. The same preparation of ${ }^{125} \mathrm{I}$-labeled soluble FBP was used in the assays shown. The values for purified folate transport protein are the means of three separate assays with standard deviations of points indicated, except for one value, which was assayed in duplicate (no SD bars shown). The values for soluble FBP shown are the means of duplicates analyzed in a typical assay. Data is expressed as percent control.

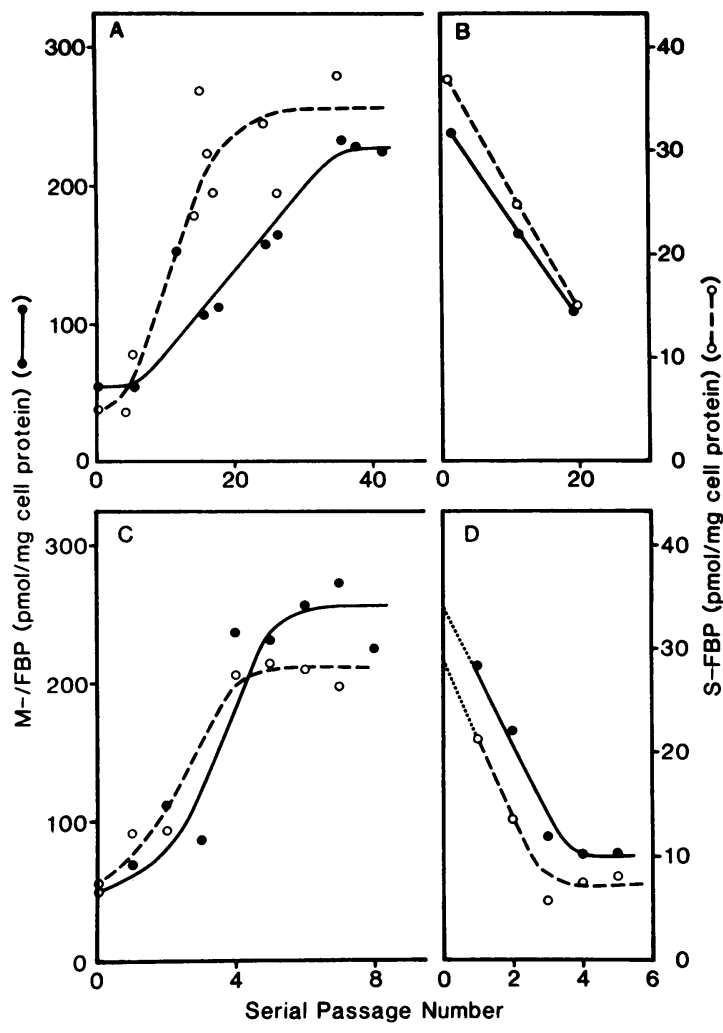

Figure 5. $(A)$ The effect of serial passage through LMEM (10 nM folate) on KB cell FBPs. $(B)$ The effect on KB cell FBPs of serial passage back into SMEM ( $2.3 \mu \mathrm{M}$ folate) of $\mathrm{KB}$ cells which had been cultured for more than 30 passes in LMEM. $(C)$ The effect of serial passage through LMEM-D on KB cell FBPs. $(D)$ The effect on KB cell FBPs of serial passage into LMEM-D ( $<2 \mathrm{nM}$ folate) supplemented with $100 \mathrm{nM} 5$-methyltetrahydrofolate, $100 \mathrm{nM}$ or $1 \mu \mathrm{M} 5$ formyltetrahydrofolate, or SMEM-D ( $2.3 \mu \mathrm{M}$ folate) after KB cells had been cultured in LMEM-D for more than 10 passes. Samples of $\mathrm{KB}$ cells and their conditioned media after the indicated number of passes were prepared as described in Methods. The folate transport protein is designated by the solid line and solid circles, and the soluble FBP, by the dashed line and open circles.

were obtained on conditioned media analyzed at $48 \mathrm{~h}$ after cell plating.

The effect on FBP levels of returning KB cells grown for more than 30 passes in LMEM into SMEM was investigated. In these KB cells, the folate transport protein and soluble FBP levels linearly fell to 110 and $15 \mathrm{pmol} / \mathrm{mg}$ cell protein, respectively, after 19 passes back into SMEM as shown in Fig. $5 B$. Extrapolation of the linear decreases in folate transport protein and soluble FBP suggested that 30-40 passes into high PteGlu medium would be required for the FBPs to return to control levels.

Fig. $5 C$ shows that folate transport protein and soluble FBP rose more rapidly in KB cells cultured in LMEM-D, but the degree of increase was the same as in KB cells cultured in LMEM. Further passage of these KB cells into LMEM-D containing added reduced folates $\left(100 \mathrm{nM} 5-\mathrm{CH}_{3} \mathrm{H}_{4} \mathrm{PteGlu}\right.$ or $0.1-1 \mu \mathrm{M} 5-\mathrm{CHOH}_{4} \mathrm{PteGlu}$ ) resulted in a rapid return of folate transport protein and soluble FBP to the same levels as those present in cells cultured in SMEM-D (Fig. 5 D). Furthermore, the addition of $100 \mathrm{nM} 5-\mathrm{CH}_{3} \mathrm{H}_{4}$ PteGlu or $0.1-1 \mu \mathrm{M}$ 
5- $\mathrm{CHOH}_{4}$ PteGlu to LMEM-D prevented the increases in folate transport protein and soluble FBP observed in KB cells serially passaged in unsupplemented LMEM-D, with results similar to those for cells maintained in SMEM-D (data not shown). This data indicates that the threshold concentration which results in FBP increases is $>10 \mathrm{nM}$ (as in LMEM), but $<100 \mathrm{nM}$ for $5-\mathrm{CH}_{3} \mathrm{H}_{4} \mathrm{PteGlu}$ or $5-\mathrm{CHOH}_{4} \mathrm{PteGlu}$, since these additions to LMEM-D prevented the increases in FBPs observed for cells cultured in LMEM (10 nM folate) or LMEM-D ( $<2 \mathrm{nM}$ folate). Since racemic mixtures of the reduced folates were used in these experiments, the possible relative efficacy and thresholds for the $D$ and $L$ isomers cannot be stated. As noted above, the maximum levels of FBP observed were the same under both of these latter conditions, but the increases occurred more rapidly in LMEM-D, just as the intracellular folate concentration dropped more rapidly. After the initial passage into SMEM-D, small increases in both the folate transport protein (to $90 \mathrm{pmol} / \mathrm{mg}$ protein) and soluble FBP (to $10 \mathrm{pmol} / \mathrm{mg}$ protein) occurred. These changes appeared to be due to the removal of nonfolate compounds by the dialysis of fetal calf serum since the levels of folate transport protein and soluble FBP remained stable thereafter as KB cells were serially passaged through SMEM-D.

Similar quantitative changes in folate transport protein levels were obtained in other cultured cells as well. Human T47D mammary tumor cells, normal human fibroblasts, normal human lymphocytes, and mouse alpha mammary tumor cells contained a membrane-associated high affinity FBP which could be solubilized with Triton X-100 and eluted with $M_{\mathrm{r}}=160,000$ when analyzed by $S 200$ gel filtration chromatography, identical with the results of the human $\mathrm{KB}$ cell folate transport protein $(19,20,22,23)$. In T47D cells, $>95 \%$ of this folate transport protein could be immunoprecipitated with chicken antiserum to the human placental folate receptor (14) ( $<5 \%$ precipitated with chicken control serum). The level of this FBP progressively increased from $7.1 \mathrm{pmol} / \mathrm{mg}$ cell protein in T47D cells cultured in SMEM-D to $22.6 \mathrm{pmol} / \mathrm{mg}$ cell protein after five serial passages into LMEM-D. Similarly, immunoreactive FBP increased six-fold in mouse alpha mammary cells and two- to four-fold in their medium after nine passes in low folate medium. Thus, the upregulation of the folate transport protein in cells exposed to a low extracellular folate concentration was not a unique property of human $\mathrm{KB}$ cells.

\section{Discussion}

Slowing of the growth rate and increase in cell size of $\mathrm{KB}$ cells grown in LMEM or LMEM-D after five to six serial passes in these media correlated with the rapid drop in cellular folate content to $1 \mathrm{pmol} / 10^{6}$ cells and $0.3 \mathrm{pmol} / 10^{6}$ cells, respectively. Recovery of growth rates to those of cells in SMEM and SMEM-D, respectively, was accompanied by an increase in both the cell-associated folate transport protein and the soluble FBP. The rate of FBP increase was more rapid in KB cells passaged in LMEM-D, which contained folate levels lower than those reported for normal nonhepatic tissues. The slower rate of increase in folate transport protein in the $\mathrm{KB}$ cells serially passaged in LMEM reflected their more adequate folate content secondary to their higher extracellular folate concentration.
An increase in cellular folate content above $1 \mathrm{pmol} / 10^{6}$ cells did not accompany the increase in folate transport protein, however. Several properties of the folate-FBP system may explain this. First, folate transport protein and soluble FBP levels in "control" KB cells cultured in the very high PteGlu levels in SMEM and SMEM-D may be artifactually low compared with the normal physiologic situation due to downregulation as a result of the extremely high intracellular folate levels. Secondly, although cell-associated folate transport protein appears to be involved in folate uptake by cells, $\sim 60 \%$ of the total cell-associated folate transport protein is insensitive to trypsin and appears to be intracellular. This intracellular portion has been postulated to play a role in intracellular folate availability and retention of folates by cells, and its upregulation may result in more efficient intracellular folate utilization. Thirdly, the intracellular folate levels necessary for normal cellular metabolism in nonhepatic tissues appear to be on the order of $1 \mathrm{pmol} / 10^{6}$ cells, much lower than in the "control" cells.

Thus, the fall in intracellular folate levels as KB cells are maintained in physiologic (LMEM) or low (LMEM-D) extracellular folate concentration apparently stimulates the cell to increase the levels of cell-associated folate transport protein in order to maintain an adequate uptake and content of cellular folates. Although not studied here, the composition of the intracellular folate pool may be changing during the FBP upregulation, and the distribution of the cell-associated FBP between its transport function and its intracellular role may favor the transport, rather than the retention, compartment. The lower folate content of KB cells in SMEM-D compared with SMEM suggests that folate retention by cells may, in part, depend upon the extracellular $5-\mathrm{CH}_{3} \mathrm{H}_{4} \mathrm{PteGlu}$ concentration and/or nonfolate soluble dialyzable factors present in serum. When KB cells were passaged into media containing unphysiologically low folate concentrations (LMEM-D), the cellular folate concentration rapidly fell, then rose as the quantity of folate transport protein increased. Despite this increase in cellular folate, the final folate level was $<1 \mathrm{pmol} / 10^{6}$ cells and the doubling time did not return to "normal" (i.e., $24 \mathrm{~h}$ ) until after the cells were placed in media containing physiologic folate concentrations that resulted in a rapid increase in the cellular folate to 1 pmol or greater per $10^{6}$ cells. Endogenous folate levels in normal human erythrocytes and leukocytes $(52,53)$, are $\sim 1 \mathrm{pmol} / 10^{6}$ cells. Human K562 cells failed to demonstrate any alteration in their DNA synthesis until cellular folate levels were $<1 \mathrm{pmol} / 10^{6}$ cells (54). Since the KB cells cultured in LMEM contained more nearly physiologic levels of folate than cells cultured in SMEM, their properties of folate acquisition may more nearly reflect the physiologic situation.

Quantitative FBP levels were two- to threefold higher for folate transport protein and five- to sixfold higher for soluble FBP as determined by RIA vs. $\left[{ }^{3} \mathrm{H}\right]$ folic acid binding assay when data in Figs. 1 and 5 are compared. This difference could have been due to artifacts in the binding assay such as: $(a)$ inadequate removal of endogenous folate from samples analyzed by binding assay; $(b)$ inaccurate $\left[{ }^{3} \mathrm{H}\right]$ folic acid specific activity, which would result in lower apparent values; $(c)$ denaturation of binding sites by acid treatment for folate removal; (d) loss of FBP during binding assay due to nonspecific adsorption to the dextran-coated charcoal. The acid dialysis procedure was successful at removing endogenous folate as evidenced by the linearity observed in binding results when dif- 
ferent volumes of the same samples were analyzed. The [ $\left.{ }^{3} \mathrm{H}\right] \mathrm{PteGlu}$ was radiochemically pure as determined by HPLC analysis. More than $95 \%$ could be adsorbed to dextran-coated charcoal and at least $80 \%$ could be bound by FBP in the binding assay. Denaturation of the FBPs during acid dialysis did not occur as samples from KB cells maintained in LMEM or LMEM-D had similar results by binding assay before and after dialysis. Finally, since the estimates of the molecular weights of the FBPs were based on $\left[{ }^{3} \mathrm{H}\right]$ folic acid binding, protein assays and a 1:1 stoichiometry, significant adsorption of the FBPs themselves to the dextran-coated charcoal seems unlikely. These estimated molecular weights are 5-10\% lower than those reported and this could be due to a small amount of FBP adsorption. However, this is negligible compared with the observed differences in levels of FBP obtained by $\left[{ }^{3} \mathrm{H}\right]$ folic acid binding vs. RIA. Thus, this difference does not appear to be due to artifacts in the binding assay. Another more likely explanation is that the RIA which employs a specific polyclonal antiserum is detecting nonfolate-binding FBP precursor or degradation products that contain immunoreactive, but nonfolate-binding domains.

Although only one immunoreactive peak was observed from Triton-solubilized KB cells which coeluted with the peak of $\left[{ }^{3} \mathrm{H}\right]$ folic acid binding on Sephacryl S200 (46), quantitation of the folate transport protein by binding was not given for comparison and thus the relative values could have been markedly different. This does not appear to be an artifact in that the ratio of values obtained by binding assay and by RIA are always 2-2.5 for the folate transport protein and 5-6 for S-FBP, whether from cells cultured in SMEM or LMEM. Therefore, the presence of immunologically cross-reactive, but nonfolate binding, precursor or degradative moieties of the folate transport protein, and probably degradative fragments of the S-FBP is the most likely explanation for the difference observed.

The possibility was considered that the increases in folate transport protein and soluble FBP were due to the selection of a clone of high FBP-containing cells during the adaptation to low folate medium rather than to upregulation. However, this possibility did not account for all of the observed changes, especially the rapid decreases in folate transport protein and soluble FBP levels in cells returned to high folate medium after serial passage through low folate medium. In addition, preliminary data on clones of KB cells cultured in high folate medium show similar levels of folate transport protein for all clones studied (Kane and Waxman, unpublished observations).

Pulse-chase studies of the FBPs of KB cells indicate that folate transport protein is the precursor of soluble FBP (22). That soluble FBP levels rose and fell as did those of folate transport protein, as well as the essentially identical immunoreactivities of these two proteins observed in the RIA, is consistent with this precursor-product relationship. This evidence suggests that the soluble FBP in human serum may arise from the cellular folate transport protein in a similar manner, and this point deserves further study.

Since the RIA measured both apo- and holo-FBP equally, the possibility of incorrect results due to interference by endogenous folates that may be obtained when ligand binding or uptake is used to quantify FBPs, especially in cells cultured in medium containing high folate levels, was avoided. The slowing of growth rates, marked increases in both the folate trans- port protein and soluble FBP in KB cells grown in LMEM ( $<10 \mathrm{nM}$ folate), and the more rapid increases in $\mathrm{KB}$ cells grown in LMEM-D ( $<2 \mathrm{nM}$ folate) suggested that these proteins are extremely important in cellular folate acquisition. These increases may have allowed the $\mathrm{KB}$ cells to adapt to the lower extracellular folate concentration.

Prevention of changes in folate transport protein and soluble FBP levels by the addition of reduced folates to LMEM-D, as well as rapid decreases in folate transport protein and soluble FBP that occurred after the addition of reduced folates to the growth media, indicated that it was the folates, and not some other dialyzable factor in FBS, that were key determinants of the cellular changes leading to upregulation and downregulation of the folate transport system. In $\mathrm{KB}$ cells maintained in SMEM or SMEM-D, the great excess of cellular folates over folate transport protein indicated a high degree of saturation with endogenous ligand, whereas folate transport protein was present in great excess over cellular folates in KB cells serially passed in LMEM or LMEM-D. The actual intracellular form(s) of folate, or specific metabolites requiring folate coenzymes for their synthesis or conversion, which stimulate the intracellular mechanism for folate transport protein upregulation have not been identified in these studies. Also, the mechanism by which the increases took place, e.g., gene amplification, increased rate of transcription or translation, reduced rate of degradation, remain to be elucidated, although karyotypes of KB cells adapted to LMEM for 19 passes contained no double minute chromosomes or homogeneous staining regions and could not be distinguished from $\mathrm{KB}$ cells maintained in SMEM.

Thus, these results clearly demonstrate for the first time in the same cell system that levels of immunoreactive soluble FBP and the folate transport protein, and not simply binding sites, were influenced by extracellular folate concentration. In addition, similar results were obtained not only with KB cells, but with cultured human and mouse mammary tumor cells. The importance of these proteins in cellular folate metabolism seems unequivocal. Further investigations are underway using the KB cell model system, as well as other human sources of cells, to define the subcellular distribution of the folate transport protein, the function of the soluble FBP, the biochemical relationship of these two proteins, and the metabolic controls and molecular mechanisms of their regulation.

\section{Acknowledgments}

We wish to thank Carol Schreiber for expert technical assistance and Susan A. Veach for her patience and persistence in the preparation of this manuscript.

This work was supported by National Research Service Award AM07300-01 (Dr. Kane), a Charles Revson Foundation Fellowship (Dr. Kane), the Cancer Chemotherapy Foundation Laboratory, Mt. Sinai Medical Center, New York, NY, National Research Service Award AM07709-02 (Dr. Elwood), National Institute of Child Health and Human Development grant 1 R01 HD20889 (Dr. Antony), March of Dimes grant 1-805 (Dr. Kolhouse), National Institutes of Health grant 26486 (Dr. Kolhouse), and National Institute of Arthritis, Diabetes, Digestive \& Kidney Diseases RCDA grant AM01069 (Dr. Kolhouse).

\section{References}

1. Ghitis, J. 1967. The folate binding in milk. Am. J. Clin. Nutr. 20:1 
2. Waxman, S., and C. Schreiber. 1973. Characteristics of folic acid-binding protein in folate-deficient serum. Blood. 42:291-301.

3. Gilbert, H. S., and S. Waxman. 1978. Vitamin binding protein release during the initial phase of phagocytosis. Clin. Res. 26:581A. (Abstr.)

4. Colman, N., and V. Herbert. 1979. Studies using the calcium ionophore A23187 suggest localization of the human granulocyte folate binder in specific (secondary) granules. Clin. Res. 27:291A. (Abstr.)

5. Waxman, S., and C. Schreiber. 1975. The purification and characterization of the low molecular weight human folate binding protein using affinity chromatography. Biochemistry. 14:5422-5428.

6. Waxman, S. 1975. Folate binding proteins. Br. J. Haematol. 29:23-29.

7. Selhub, J., and W. A. Franklin. 1984. The folate-binding protein of rat kidney. J. Biol. Chem. 259:6601-6606.

8. Rubinoff, M., C. Schreiber, and S. Waxman. 1977. The isolation and characterization of the folate binding protein from goat milk. FEBS (Fed. Eur. Biochem. Soc.) Lett. 75:244-248.

9. Kamen, B. A., and J. D. Caston. 1975. Purification of folate binding protein in normal umbilical cord serum. Proc. Natl. Acad. Sci. USA. 72:4261-4264.

10. Fischer, C., M. da Costa, and S. P. Rothenberg. 1978. Properties of purified folate binding proteins from chronic myelogenous leukemia cells. Biochim. Biophys. Acta 543:328-339.

11. Suleiman, S. A., R. Spector, and P. Cancilla. 1981. Partial purification and characterization of a folate-binding protein from human choroid plexus. Neurochem. Res. 6:333-341.

12. da Costa, M., S. P. Rothenberg, C. Fischer, and Z. Rothenberg. 1978. The identification and measurement of a folate-binding protein in human serum by radioimmunoassay. J. Lab. Clin. Med. 91:901910.

13. Antony, A. C., C. Utley, K. C. Van Horne, and J. F. Kolhouse. 1982. Isolation, characterization and comparison of the solubilized particulate and soluble folate binding proteins from human milk. $J$. Biol. Chem. 257:10081-10089.

14. Antony, A. C., C. Utley, K. C. Van Horne, and J. F. Kolhouse. 1981. Isolation and characterization of a folate receptor from human placenta. J. Biol. Chem. 256:9684-9692.

15. Corrocher, R., R. G. Abramson, V. K. King, C. Schreiber, S. Dikman, and S. Waxman. 1985. Differential binding of folates by rat renal cortex brush-border and basolateral membrane preparations. Proc. Soc. Biol. Exp. Med. 178:73-84.

16. Lyngbye, J., S. I. Hansen, and J. Holm. 1980. Kinetics of folate-binding protein. Methods Enzymol. 66:694-709.

17. Waxman, S. 1979. Studies of the origin of serum folate binding protein. In Chemistry and Biology of Pteridines. R. L. Kisliuk and G. M. Brown, editors. North Holland, Amsterdam. 619-624.

18. da Costa, M., and M. Sharon. 1980. The synthesis of folate binding proteins in lymphocytes during transformation. $\mathrm{Br}$. J. Haematol. 46:575-579.

19. Kane, M. A., A. C. Antony, and J. F. Kolhouse. 1984. Interrelationship of the two species of folate binding proteins in human cells. Clin. Res. 32:310A. (Abstr.)

20. Antony, A. C., M. A. Kane, R. Portillo, P. C. Elwood, and J. F. Kolhouse. 1985. Studies of the role of a particulate folate-binding protein in the uptake of 5-methyltetrahydrofolate by cultured human KB cells. J. Biol. Chem. 260:14911-14917.

21. Kamen, B. A., and A. Capdevila. 1986. Receptor-mediated folate accumulation is regulated by the cellular folate content. Proc. Natl. Acad. Sci. USA 83:5983-5987.

22. Kane, M. A., P. C. Elwood, R. M. Portillo, A. C. Antony, and J. F. Kolhouse. 1986. The interrelationship of the soluble and membrane-associated folate-binding proteins in human KB cells. J. Biol. Chem. 261:15625-15631.

23. Elwood, P. C., M. A. Kane, R. M. Portillo, and J. F. Kolhouse. 1986. The isolation, characterization and comparison of the mem- brane-associated and soluble folate-binding proteins from human $\mathrm{KB}$ cells. J. Biol. Chem. 261:15416-15421.

24. Luhrs, C. A., E. Sadavisan, M. da Costa, and S. Rothenberg. 1986. The isolation and properties of multiple forms of folate binding protein in cultured KB cells. Arch. Biochem. Biophys. 250:94-105.

25. Sadasivan, E., S. P. Rothenberg, M. daCosta, and L. Brink. 1986. Characterization of multiple forms of folate-binding protein from human leukemia cells. Biochim. Biophys. Acta. 882:311-321.

26. Kane, M. A., R. Portillo, P. C. Elwood, A. C. Antony, and J. F. Kolhouse. 1986. The influence of extracellular folate concentration on methotrexate uptake by human KB cells. J. Biol. Chem. 261:44-49.

27. Izhak, G., K. Galewski, M. Rachmilewitz, and N. Grossowicz. 1972. The absorption of milk-bound pteroylglutamic acid from small intestine segments. Proc. Soc. Exp. Biol. Med. 140:248-250.

28. Ford, J. E. 1974. Some observations on the possible nutritional significance of vitamin $\mathrm{B}_{12}$ - and folate-binding proteins in milk. $\mathrm{Br}$. $\mathrm{J}$. Nutr. 31:243.

29. da Costa, M., and S. P. Rothenberg. 1976. Studies with the folate binding protein in chronic granulocytic leukaemia cells. $B r . J$. Haematol. 34:581-587.

30. McHugh, M., and Y. C. Cheng. 1979. Demonstration of a high affinity folate binder in human cell membranes and its characterization in cultured human KB cells. J. Biol. Chem. 254:11312-11318.

31. Fernandes-Costa, F., and J. Metz. 1979. Role of folate binders in the delivery of folate to tissues and to the fetus. Br. J. Haematol. 41:335-342.

32. Waxman, S., and C. Schreiber. 1974. The role of folic acid binding proteins (FABP) in the cellular uptake of folates. Proc. Soc. Exp. Biol. Med. 147:760-764.

33. Rothenberg, S. P., C. D. Fischer, and M. da Costa. 1978. Binding of $\mathrm{N}^{5}, \mathrm{~N}^{10}$-methylenetetrahydrofolate and the inhibition of thymidylate synthesis by a folate-binding protein. Biochim. Biophys. Acta. 543:340-348.

34. Colman, N., N. Hettiarachchy, and V. Herbert. 1981. Detection of a milk factor that facilitates folate uptake by intestinal cells. Science (Wash. DC). 211:1427-1429.

35. Carpenter, G., and S. Cohen. 1976. ${ }^{125}$ I-labeled human epidermal growth factor. J. Cell Biol. 71:159-171.

36. Changeux, J. P. 1980. The acetylcholine receptor: an "allosteric" membrane protein. Harvey Lect. 75:85-254.

37. da Costa, M., S. P. Rothenberg, and R. Raffaniello. 1984. Induction of an apo form of folate binding protein in liver of folate-deficient rats. Clin. Res. 32:544A. (Abstr.)

38. Henderson, G. B., E. M. Zevely, and F. M. Huennekens. 1976. Folate transport in Lactobacillus casei: solubilization and general properties of the binding protein. Biochem. Biophys. Res. Commun. 68:712-717.

39. da Costa, M., and C. Fischer. 1981. Immunologic heterogeneity of the folate-binding proteins from chronic myelogenous leukemia cells and myelofibrosis spleen. J. Lab. Clin. Med. 98:956-963.

40. Patterson, M. K. 1979. Measurement of growth and viability of cells in culture. Methods Enzymol. 58:141-152.

41. Rittinghausen, R., H. W. Schwab, H. Breer, B. Schellenberg, and $H$. Schmidt-Gayk. 1983. Rapid simultaneous radioassay of vitamin $B_{12}$ and folate in the radioassay vial. Arztl. Lab. 29:90-94.

42. Hunter, W. M., and F. C. Greenwood. 1962. Preparation of iodine-131-labeled human growth hormone of high specific activity. Nature (Lond.). 194:495-496.

43. Schneider, R. J., R. L. Burger, C. S. Mehlman, and R. H. Allen. 1976. The role and fate of rabbit and human transcobalamin II in the plasma transport of vitamin $B_{12}$ in the rabbit. J. Clin. Invest. 57:27-38.

44. Laemmli, U. K. 1970. Cleavage of structural proteins during the assembly of the head of bacteriophage T4. Nature (Lond.). 227:680-685.

45. Gray, J. E., D. W. Patin, and D. H. Calhoun. 1981. Identification of the protein products of the $\mathrm{rrnC}$, ilv, rho region of the Escherichia coli K-12 chromosome. Mol. Gen. Genetics 183:428-436. 
46. Antony, A. C., R. S. Verma, and R. S. Kincade. 1987. Development of a specific radioimmunoassay for the placental folate receptor and related high-affinity folate binding proteins in human tissues. Anal. Biochem. 162:224-235.

47. Waxman, S., and C. Schreiber. 1980. Determination of folate by use of radioactive folate and binding proteins. Methods Enzymol. 66:468-483.

48. Lowry, O. H., N. J. Rosebrough, A. L. Farr, and R. T. Randall. 1951. Protein measurement with the folin phenol reagent. J. Biol. Chem. 193:265-275.

49. Wang, C., and R. L. Smith. 1975. Lowry determination of protein in the presence of Triton X-100. Anal. Biochem. 63:414-417.

50. Lewis, A. E. 1984. The null hypothesis and the comparison of means. In Biostatistics. 2nd edition. Van Nostrand Reinhold Co., New York. 52-65.

51. Summer, A. T., Evans, H. J., and Buckland, R. A. 1971. A new technique for distinguishing between human chromosomes. Nat. (New Biol.) 232:31.

52. International system for human cytogenetic nomenclature. 1985. Birth Defects Orig. Artic. Ser. 21:1-117.

53. Kamen, B. A., V. S. Holcenberg, K. Turo, and V. M. Whitehead. 1984. Methotrexate and folate content of erythrocytes in patients receiving oral vs intramuscular therapy with methotrexate. J. Pediatr. 104:131-133.

54. Sullivan, P. W., and S. E. Salmon. 1972. Kinetics of tumor growth and regression in IgG multiple myeloma. J. Clin. Invest. 51:1697-1708.

55. Watkins, D., T. E. Shapiro, and B. A. Cooper. 1983. Intracellular folate concentration and growth rate in folate-depleted K562 human leukemia cells. In Biochemical and Clinical Aspects of Pteridines. Vol. 2. Walter de Gruyter \& Co., New York. 351-365. 